удк 340.1

DOI https://doi.org/10.32837/pyuv.v1i4(29).388

\author{
І. Д. Веркалець \\ orcid.org/0000-0002-2411-2811 \\ аспірант спеиіальності 081 «Право» \\ Університету Короля Данила
}

\title{
ЮРИДИЧНЕ ЗАКРІПЛЕННЯ ТА РЕАЛІЗАЦІЯ ФУНКЦІЙ ПРАВА В КОНТЕКСТІ ЗАГАЛЬНОГО РІВНЯ ПРАВОСВІДОМОСТІ
}

Складний динамічний характер правової реальності зумовлює необхідність визначення їі функціонального призначення. Дослідження категорії «функції» у сфері права не надає можливості констатувати наявність єдиного погляду на цю проблему. Це зумовлено особливістю та запозиченням категорії «функції» з інших наук, складністю правових явищ як багатоаспектних та поліструктурних, а також відсутністю єдності в поглядах на правову реальність, правовому свідомість та їхні основні складники.

Функція права випливає з іï сутності і визначається призначенням права в суспільстві. Функції - це фактично відображення сутності права в суспільних відносинах. Водночас повністю солідаризуємось із дослідником П. Рабіновичем у тому, що будучи проявом іманентних властивостей сутності, функції не зводяться до них і не є простою ïx проєкцією. Не можна механічно пов'язувати функції і сутність права, адже настільки явище завжди містить момент незалежності від сутності, так і функція права має певну ступінь незалежності від його сутності. Отже, функція права, як визначає дослідник, - це такий напрям його впливу на суспільні відносини, потреба в здійсненні якого породжує необхідність існування права як соціального явища. У цьому сенсі можна сказати, що функція характеризує напрям необхідного впливу права, без якого суспільство на конкретному етапі розвитку обійтися не може (регулювання, охорона, закріплення певного виду суспільних відносин) [9, с. 94].

Функція виражає найбільш істотні, головні риси права і спрямована на здійснення корінних завдань, що стоять перед правом на даному етапі його розвитку. Функція права виявляє, як було вже зазначено, напрям його активного впливу, покликаного впорядкувати певний вид суспільних відносин. Тому однією з іманентних ознак функції права $є$ іiї динамізм. Водночас про перманентний характер функції права можна говорити в тому сенсі, що вона постійно властива праву. Але це не означає, що незмінним залишається механізм і форми її здійснення, які змінюються і розвиваються відповідно до потреб практики.

Функціональність права є його інтегральною й універсальною характеристикою, вираженням його природи і характерна для будь-якої правової системи на всіх історичних етапах її розвитку. Функція права виявляється водночас у суспільному бутті й у свідомості індивіда.

Науковці наголошують, що правосвідомість виявляється на всіх стадіях механізму правового регулювання, впливає на функціонування практично кожного елемента правової системи [7, с. 353]. Одним із найбільш поширених є розуміння функцій правосвідомості як напрямів впливу цього явища на суспільні відносини [13. с. 618], [14, с. 555]. Таке розуміння фактично відповідає традиційним уявленням про функції права [3, с. 110$] \mathrm{i}$, загалом, правильно характеризує функціонування правосвідомості. Однак варто уточнити, що основне призначення права полягає саме в регулюванні суспільних відносин, натомість правосвідомість суспільні відносини безпосередньо не регулює, її регулятивна сила спрямована на внутрішній світ людини, її переконання та оцінки. Інакше кажучи, правосвідомість регулює поведінку людей, її можна розглядати як спосіб впливу права через свідомість окремих індивідів на закріплення навичок їхньої правової позитивної поведінки. Таким чином, вплив правосвідомості на суспільні відносини є опосередкованим: прямо впливаючи на поведінку людей, правосвідомість впливає і на суспільні відносини, що виникають між ними. У зв'язку з цим вважаємо, що визначення функцій правосвідомості потребує уточнення щодо об'єкта впливу даного феномену. У цьому контексті слушним уявляється зауваження О.Ф. Скакун, яка вважає правосвідомість суб'єктивною формою реалізації функцій права [12, с. 91$]$.

Відомо, що структуру правової свідомості становлять три складники: правові знання, правові оцінки і правові установки. Більшість учених виділяють два елементи іï структури: правову ідеологію і правову психологію. Як уявляється, в сучасному суспільстві правова ідеологія відіграє провідну роль, що зумовлено передовсім «юридизацією» суспільного життя, підвищенням значення правових регулятивних та охоронних інститутів, перетворенням правових цінностей на інтегративну, цементуючу основу суспільної свідомості. Функція правової ідеології у найбільш 
загальному вигляді - це утворення їі інтелектуально-вольової сфери, накопичення знань про право, правову дійсність загалом, що у свою чергу становить основу для формування відповідного ставлення до права, вироблення правових установок, націленості на ті чи інші варіанти поведінки. Інакше кажучи, саме правова ідеологія як елемент правосвідомості виконує пізнавальну функцію [12, с. 91].

Отже, пізнавальна (або інформативно-пізнавальна) функція правосвідомості полягає в тому, що людина на основі набутих юридичних знань та юридичного досвіду формує уявлення про чинне право, зокрема, про свої суб'єктивні права і юридичні обов' язки. Зазначимо, що ефективність вказаної функції правосвідомості залежить від рівня правової інформованості людини та залучення їі до системи правових відносин. Джерелами правової інформації є документальні юридичні акти, оприлюднені в установленому законом порядку, повідомлення преси, радіо і телебачення, публічні виступи державних і громадських діячів тощо, а джерелом правового досвіду - практичні дії людини у сфері права.

Правова психологія - найпоширеніша форма сприйняття права, яка тією чи іншою мірою властива всім людям, колективам людей, соціальним групам; до змісту її передовсім належать правові емоції, почуття, настрої. Сучасна наука долає уявлення про правову психологію як другорядну i менш важливу, порівняно з правовою ідеологією, складову частину правосвідомості. На думку О.Ф. Скакун, було б неправильно принижувати значення емоцій і почуттів (правову психологію) порівняно 3 інтелектом (правовою ідеологією). Емоції і почуття - необхідний грунт, на якому виявляються (складаються, реалізуються) правові погляди, ідеї, теорії [12, с. 95].

Функції права як основні напрями правової дії на громадське життя неодмінно мають бути реалізовані. Відсутність реалізації функцій права означатиме, що право не діє, не робить впливу, тобто не має ніякої соціальної цінності. При цьому не можна не вказати на те, що хоча категорія «реалізація права» у вітчизняній юридичній науці проаналізована дуже детально, основні аспекти реалізації функцій права практично не дослідилися. Як справедливо відмічає А. Абрамов, сьогодні, попри те, що термін "реалізація функцій права» досить широко вживається в юридичній літературі, це поняття в науці розроблене недостатньо [1, с. 179$]$.

Дослідник Р. Зварич зазначає, що в сучасній літературі із загальної теорії права традиційно пропонують дві групи критеріїв класифікації функцій права - зовнішні (такі, що знаходяться за межами права) і внутрішні (такі, що знаходяться в його межах). За зовнішнім критерієм виділяють так звані соціальні функції права (політичну, економічну, ідеологічну, культурно-виховну, інформаційну ті ін.), за внутрішнім критерієм - основні власне юридичні функції (регулятивну, охоронну і захисну). В залежності від значення та сутнісних властивостей правового впливу функції права поділяють на основні (регулятивну, охоронну) і неосновні (обмежувальну, компенсаційну, відновлювальну, інформаційну, екологічну та інші) [4, c. 35].

У вказаній сфері існує чимало дискусійних питань. Найконцептуальніше з них полягає в такому: чи збігається зміст категорій "реалізація права» і «реалізація функцій права»? Тут ми вважаємо за можливе підтримати найбільш поширену позицію, згідно з якою поняття «реалізація права» і «реалізація функцій права», безперечно, мають немало спільного, проте вони не ідентичні в усіх відношеннях [1, с. 180].

Через функції як основні напрями його впливу на соціальне i духовне життя проявляється суть права. Функціональна характеристика права дозволяє визначити, яким чином право імплементується в суспільне життя, які зміни спричиняє. При цьому слід підкреслити, що право є потужним засобом не лише регламентації соціальних процесів, але і впливу на духовну сферу, на сферу цінностей, ідеологіі, свідомості людей. Функціональна характеристика права, що відображає його в динаміці, є базовою для досягнення розуміння соціального призначення права.

На слушну думку Т. Радько, поняття «функція права» повинне одночасно охоплювати як призначення права, так і напрями його впливу на суспільні відносини, а також ефективність і легітимність державних інституцій. Тому, аналізуючи доцільність застосування тієї чи іншої функції права, необхідно постійно мати на увазі зв'язок призначення права з основними напрямами його впливу на суспільство, і навпаки - залежність останніх від призначення права. Функція права в розумінні дослідника полягає в єдності двох моментів: призначення права в суспільстві й основних напрямів його впливу на суспільство й державні інституції $[11$, с. 25$]$.

Далі, згідно з позицією Т. Радько, як соціальне призначення права, так і основні напрями його впливу на суспільні відносини, взяті окремо, не вичерпують собою поняття функції права. Якщо під функцією права розуміти тільки його соціальне призначення, то подібне поняття носитиме занадто загальний характер. По-перше, сам термін «соціальне призначення» вживається в декількох сенсах. По-друге, ми фактично ототожнюємо його з цілями і завданнями, які покликане вирішувати право, оскільки призначення характеризує право з точки зору того, що повинне воно робити відповідно до цілей держави, всього суспільства, 
вираженням волі яких воно є. Водночас під час визначення функції права тільки як основного напряму впливу на суспільні відносини не береться до уваги рушійна сила цього впливу. За такого розуміння є велика небезпека загубитися в масі подробиць і деталей, упустити головне, сутнісне. У цьому плані з позицією Т. Радько можна погодитися і підкреслити, що функції як основні напрями впливу права без виконання його соціального призначення з'являються як випадкові, такі, що не мають сенсу й обгрунтування [11, с. 26].

Основне призначення ж самих функцій права полягає в опосередкуванні зв'язків між правом і об'єктами його дії - суспільними відносинами, свідомістю людей, іншими чинниками соціальної дійсності [2, с. 80.] Зважаючи на викладене вище, стверджуємо, що в послідовності об’єктів впливу функцій права на перше місце має бути поставлена особа, її світогляд, потреби й інтереси, можливості для самореалізації, соціально корисної діяльності, а потім уже власне забезпечення ефективної діяльності державних інституцій та суспільні відносини.

Функції права можна розглядати і як концентрований прояв його специфічних властивостей. При цьому, на наш погляд, необхідно мати на увазі не лише їх множинність, але і їхню роль, місце у формуванні самостійного основного напряму впливу на особу і суспільні відносини.

Функції права отримують втілення в основних напрямах діяльності Української держави, зокрема в державних та регіональних програмах. Прагматичний аспект функцій права випливає iз завдань базових нормативно-правових актів у конкретний історичний період, обслуговування і захисту соціально-прийнятних інтересів. Залежність функцій права від цих завдань та інтересів дістає вияв у тому, що вони тісно пов'язані між собою, адже часто безпосередньо зумовлюють саме існування функцій, визначають їхній зміст, а також суттєво впливають на історично зумовлені форми їх реалізації, на функціонування певних державних інституцій. Отже, функції та функціонування права $€$ пов'язаними проявами його дії [15, с. 211]. У цьому зв'язку необхідно розрізняти основні (сутнісні) та похідні (атрибутивні) завдання функцій права. Перші, так би мовити, основні, завдання відбиваються, на нашу думку, в принципах та напрямах політики держави (внутрішньої, соціальної, правової), напрямах та стилі управлінської діяльності (авторитарному, демократичному, технократичному). Інші, або похідні завдання втілюються у правових режимах, певному напрямі діяльності (обвинувальному в досудовому слідстві чи каральному - у внутрішній політиці держави, соціальному захисті прав i свобод людини, вертикально підпорядкованій бюджетній політиці, у певних засобах підтримки національної валюти, забезпечення митних режимів, захисті вітчизняного товаровиробника тощо) i спираються саме на конституційні принципи державної внутрішньої політики.

Поряд із процесом реалізації функцій права постає питання щодо форм їх реалізації. Т.Я. Радько вважає, що якщо розглядати функції права 3 позицій того впливу, що здійснюється правом, то стає можливим виокремлення трьох основних форм: інформаційної, орієнтаційної та правового регулювання. Інформаційна форма реалізації функцій права полягає в тому, щоб повідомити адресатам вимоги держави, які стосуються поведінки людей. Наступною, не менш значущою формою реалізації функцій права є орієнтаційна, суть якої полягає у здійсненні орієнтаційного правового впливу та виробленні у громадян позитивних правових установок, які у своїй сукупності утворюють правову орієнтацію [8, с. 208].

Центральне місце в системі форм реалізації функцій права займає правове регулювання, оскільки воно для права вважається безпосереднім юридичним впливом і здійснюється за допомогою особливої системи правових засобів, які у своїй сукупності утворюють механізм правового регулювання. Як вже було зазначено, реалізація права і реалізація функцій права не є тотожними [10, с. 92].

Сучасний реальний механізм практичної реалізації концепції правової держави в Україні потребує низки кардинальних змін правового регулювання в окремих сферах державного і суспільного життя, зокрема: конституційно-правової реформи; реформи органів місцевого самоврядування; системи освіти та соціального захисту людини; прозорого правового регулювання партнерських взаємовідносин держави і сфери приватного бізнесу; чіткого визначення основних напрямів внутрішнього розвитку та зовнішньої політики держави; консолідація влади, опозиції та громадянського суспільства; зміцнення національної свідомості громадян та сприяння розвитку інноваційних технологій тощо [5, с. 15].

Форма реалізації функцій права, виступаючи характеристикою функцій права в зовні, що виражається в ефективності і результативності правового впливу, повинна відповідати виключно об'єктивним критеріям. Інакше дуже складно буде оцінити ефективність правового впливу загалом і кожної функції права окремо.

Отже, оскільки правовідносини є однією 3 форм реалізації права, а без реалізації права неможлива реалізація його функцій (оскільки самі функції визначаються суттю і соціальним призначенням права і є похідними від нього, реалізація функцій права зумовлена реалізацією правових норм), то абсолютно очевидно, що правовідносини є тією сферою (формою), в якій також відбувається реалізація функцій права [1, с. 185]. 
Тісний взаємозв’ язок між категоріями «функції права» i «правовідносини» проявляється і в інших аспектах. Зокрема, право традиційно наділяється двома головними власне юридичними функціями регулятивною й охоронною, саме вони найбільшою мірою відображають соціальне призначення права, цілі і завдання, що стоять перед ним.

Проаналізована проблематика характеризується новизною та масштабністю завдань державного будівництва, поєднанням багатьох інститутів, зокрема, охорони та захисту як у публічній, так i приватній сферах правового регулювання суміжних галузей права. Це стосується, безумовно, і взаємодії правових підсистем, якими є, зокрема, праворегуляційна, правоохоронна та правозахисна підсистеми, окремі інститути, що здатні належним чином функціонувати у випадку досягнення належного рівня правосвідомості більшістю громадян.

У зв'язку з цим значною мірою по-новому в розвитку правового життя постає питання про комплексні правові реалії, зокрема такі важливі інститути, як національна безпека, правовий порядок, законність, відповідальність державних інститутів за організацію соціальних процесів, розвиток демократії та становлення системи забезпечення конституційних прав людини. У реальному житті ці інститути пов'язані між собою завдяки певним правовим властивостям, якими є стабільність правових відносин, правомірність прийнятих рішень, законність у сенсі загального дотримання чинних нормативно-правових актів [6, с. 5].

Таким чином, важливість функцій відбивається в сутнісних ознаках права, включаючи мету, завдання, зміст інститутів і норм права, меж впливу тощо, а також роль, яку відіграють саме конституційні норми у формуванні засад, які в сукупності визначають соціальну і правову сутність держави, спрямовують діяльність її керівних та уповноважених органів. Тобто функції права мають бути каталізатором розвитку правової державності, проявом соціальної сутності і спрямованого поступу української держави до демократії, до людини і громадянина. Загалом, сама сутність права, якщо вона аналізується в контексті його функцій, має розглядатися у безпосередньому зв'язку з процесами соціалізації індивідів і самої держави, демократизації політичного життя за активної участі громадян у процесі правотворчості. Суб'єкт функцій існує для права, а право існує та визначається ним; суб'єкт - це та персона, чиєю свідомістю, ментальністю та діяльністю створюється, діє право, чиї ідеали та намагання реалізуються у праві; він є тим центром, який визначає правопорядок, існуючі правові норми, зв'язки та правовідносини.

Висновки. Підводячи підсумок дослідженню процесів юридичного закріплення та реалізації функцій права в контексті загального рівня правосвідомості, необхідно ще раз підкреслити, що право має соціальну цінність тільки тоді, коли воно чинить реальну, а не номінальну дію на стан суспільних відносин, підвищує якість державних органів та інститутів громадянського суспільства. При цьому саме якість реалізації функцій права як динамічного складника правосвідомості, на наш погляд, має ключове значення при визначенні міри ефективності сучасного українського права.

\section{Jimepamypa}

1. Абрамов А.И. Понятие реализации функций права: Соотношение понятий "реализация права" и «реализация функций права». Правоведение. 2006. № 3. С. 179-189.

2. Абрамов А.И. Понятие функции права. Журнал российского права. 2006. № 2. С. 78-85. С. 80.

3. Загальна теорія держави і права / за ред. В.В. Копєйчикова. Київ : Юрінком Інтер, 1998. 320 с.

4. Зварич Р. Трансформація регулятивної функції права: історико-правове та компаративне дослідження : дис. ... докт. юрид. наук : 12.00 .01 ; Університет Короля Данила. Івано-Франківськ, 2019. 448 с.

5. Зварич Р.В. Проблеми реалізації концепції правової держави в Україні. Європейські перспективи. Науково-практичний журнал. 2013. № 5. С. 11-15.

6. Ковальський В. Функції права: поняття, джерела, динаміка. Теорія і практика інтелектуальної власності. 2009. № 2. С. 3-10.

7. Крестовська Н.М., Матвєєва Л.Г. Теорія держави і права. Елементарний курс : навч. посіб. Харків : Одіссей, 2007. 432 c.

8. Общая теория права / под ред. В.К. Бабаева. Н. Новгород, 1993. $534 \mathrm{c.}$

9. Рабінович П.М. Основи загальної теорії права та держави : навчальний посібник. Вид. 5-те, зі змінами. Київ : Атіка, 2001. 176 с.

10. Радько Т.Н. Методологические вопросы познания функций права. Волгоград, 1974. 183 с.

11. Радько Т.Н. Основные функции социалистического права : учебное пособие. Волгоград : НИиРИО ВСШ МВД СССР, 1970. $254 \mathrm{c}$.

12. Скакун О.Ф. Теорія права і держави : підручник. Київ : Алерта ; КНТ ; ЦУЛ, 2010. 603 с.

13. Теория государства и права : курс лекций / под ред. Н.И. Матузова, А.В. Малько. 2-е изд., перераб. и доп. Москва : Юристъ, 2007. 786 с.

14. Теорія держави і права. Академічний курс : підручник / за ред. О. В. Зайчука, Н. М. Оніщенко. Київ : Юрінком Інтер, 2006. 688 с.

15. Теорія держави і права. Академічний курс : підручник / за ред. О.В. Зайчука, Н.М. Оніщенко. 2-ге вид., перероб. і допов. Київ : Юрінком Інтер, 2008. С. 319.

\section{Анотація}

Веркалеиь I. Д. Юридичне закріплення та реалізація функцій права в контексті загального рівня правосвідомості. - Стаття.

У статті проаналізовано особливості юридичного закріплення функцій права. Охарактеризовано зміст функцій сучасного українського права та їх реалізаціі в контексті правової свідомості. 3'ясовано, що функція виражає найбільш істотні, головні риси права і спрямована на здійснення корінних завдань, що стоять перед правом на даному етапі його розвитку. Функція права виявляє, як було вже зазначено, напрям його активного впливу, покликаного впорядкувати певний вид суспільних відносин. Функціональність права є його 
інтегральною та універсальною характеристикою, вираженням його природи і характерна для будь-якої правової системи на всіх історичних етапах її розвитку. Функція права виявляються водночас у суспільному бутті й у свідомості індивіда. Визначено, що основне призначення права полягає саме в регулюванні суспільних відносин, натомість правосвідомість суспільні відносини безпосередньо не регулює, її регулятивна сила спрямована на внутрішній світ людини, ії переконання та оцінки. Інакше кажучи, правосвідомість регулює поведінку людей: правосвідомість можна розглядати як спосіб впливу права через свідомість окремих індивідів на закріплення навичок їхньої правової позитивної поведінки. Таким чином, вплив правосвідомості на суспільні відносини є опосередкованим: прямо впливаючи на поведінку людей, правосвідомість впливає і на суспільні відносини, що виникають між ними. У зв'язку з цим вважаємо, що визначення функцій правосвідомості потребує уточнення щодо об'єкта впливу даного феномену. Наголошено, що форма реалізації функцій права, виступаючи характеристикою функцій права в зовні, що виражається в ефективності й результативності правового впливу, повинна відповідати виключно об'єктивним критеріям. Інакше дуже складно буде оцінити ефективність правового впливу загалом і кожної функції права окремо. Зроблено висновок, що право має соціальну цінність тільки тоді, коли воно чинить реальну, а не номінальну дію на стан суспільних відносин, підвищує якість державних органів та інститутів громадянського суспільства. При цьому саме якість реалізації функцій права як динамічної складової частини правосвідомості, на наш погляд, має ключове значення під час визначення міри ефективності сучасного українського права.

Ключові слова: функція, функції права, правосвідомість, функції правосвідомості, реалізація функцій права.

\section{Summary}

Verkalets I. D. Statutory consolidation and implementation of the functions of law in the context of general level of legal consciousness. - Article.

The article analyzes the features of the legal consolidation of the functions of law. It characterizes the content of the functions of modern Ukrainian law and their implementation in the context of legal awareness. It has been found out that the function expresses the most essential, main features of the law and is aimed at accomplishing the fundamental tasks that the law faces at this stage of its development. The function of law reveals, as already stated, the direction of its active influence, designed to regulate a certain type of social relations. Functionality of law is its integral and universal characteristic, expression of its nature and characteristic of any legal system at all historical stages of its development. The function of law is manifested at the same time in public life and in the mind of the individual. It is determined that the main purpose of law lies precisely in the regulation of social relations, while the legal consciousness does not directly regulate social relations. In other words, justice regulates people's behavior: justice can be seen as a way of influencing law through the consciousness of individuals to consolidate the skills of their legal positive behavior. Thus, the influence of justice on social relations is indirect: directly affecting the behavior of people, justice also affects the social relations that arise between them. In this regard, we believe that defining the functions of consciousness requires clarification about the object of influence of this phenomenon. It is emphasized that the form of implementation of the functions of law, acting as a characteristic of the functions of law externally, which is expressed in the efficiency and effectiveness of legal influence, must meet only objective criteria. Otherwise, it will be very difficult to evaluate the effectiveness of the legal impact in general and each function of law separately. It is concluded that law has social value only when it has real, and not nominal, effect on the state of public relations, and improves the quality of state bodies and institutions of civil society. At the same time, in our opinion, the quality of implementation of the functions of law as a dynamic component of justice is of key importance in determining the degree of effectiveness of modern Ukrainian law.

Key words: function, functions of law, legal awareness, functions of justice, implementation of functions of law. 